Václav Lábus - Daniel Vrbík

\title{
POZNÁMKY K TZV. OBJEKTOVÉ FIXACI TOPONYM
}

\author{
REMARKS ON SO-CALLED OBJECT FIXATION \\ OF TOPONYMS
}

\begin{abstract}
The paper focuses on so-called object fixation of toponyms, that is, how users perceive the toponym in real space, or more precisely, in their mental reflection of real space. In the first part of the paper, the authors discriminate between individual object fixation of a particular user, and a core of object fixation as the intersection of these individual localizations. As the authors point out, a kind of social and spatial information is encoded in the individual toponyms as a necessary part of their proprial content. In the second part of the paper, the authors discuss the problem of fixation changes (either quantitative, or qualitative ones), and their difference from transonymization. The third part is aimed at research in the core of object fixation by geographic information system tools and methods. From the authors' experience ensue two necessary requirements for such kind of research, and these are a) sufficient number of respondents who have at least a basic ability for spatial orientation, and b) the researched toponyms should be part of a toponymic centre (i.e. known to most of respondents).
\end{abstract}

\section{KEYWORDS}

geographic information system; object fixation; toponym; toponymic object; transonymization

\section{1 Úvodem}

Př́spěvek se zabývá problematikou geografické fixace toponym, jejím vymezením, změnami a možnostmi jejího zkoumání. Materiálovým východiskem jsou toponyma z katastru obce Lučany nad Nisou (původně Wiesenthal an der Neisse) v okresu Jablonec nad Nisou. Zdejší toponymie byla zásadně ovlivněna poválečnou výměnou obyvatelstva a z ní vyplývající radikální přestavbou orientačního systému (LÁBUS 2018). 
České a německé formy pojmenování téhož objektu považujeme za diachronní/ substituční varianty (srov. KRŠKo 2002, 144; LÁBUS - VRBík 2018, 80) a při úvahách o jejich objektové fixaci je považujeme za ekvivalentní. Česká pojmenování mohou označovat objekty bez původního německého označení ( $N a$ kolečku), a tedy zpravidla vzniklé až po roce 1945, častěji ale navazují na původní německojazyčný toponymický systém a vznikají bud' doslovným překladem (Erbseberg > Hrachový kopec), volným př̀ekladem (Bei der Bleiche $>$ Na bělidle), popř. chybným překladem (Tischerberg > Stolní vrch, správně ,Tischerův vrch'), nebo formální adaptací (Freischütz > Frajšic) či nezávisle (Bramberg > Krásný).

\section{Objektová fixace toponym a její vymezení}

Fixaci propria chápe R. Šrámek ,jako odraz stabilizovaného vztahu mezi propriem a pojmenovaným objektem zařazeným (umístěným) v množině objektů téže tř́dy“ (ŠRÁMEK 1999, 68). Autor rozlišuje fixaci jazykově systémovou a fixaci objektově systémovou, již v př́padě toponym označuje jako geograficky prostorovou: „Geonymické objekty jsou fixovány v geomorfologických systémech, které jsou topograficky zjistitelné a kartograficky určitelné v bodech majících své souřadnice, popr. které jsou lokalizovatelné vzhledem k bodům jiným." (ŠRÁMEK 1999, 68) Následující výklady se týkají problematiky geograficky prostorové fixace, kterou zde označujeme jako objektovou fixaci toponym. K fixaci jazykově systémové se přihlíží jen okrajově.

$\mathrm{Z}$ výše uvedených definic vyplývá, že objektová fixace toponyma reprezentuje jeho referenční vztah ke geograficky vymezitelnému objektu ukotvenému v krajině. Toponyma jsou ale primárně sociálním a komunikačním konstruktem. $\mathrm{Z}$ toho důvodu je vhodné hovořit spíše o fixaci toponyma v představě, kterou o reálném geografickém prostoru má pojmenovatel objektu či uživatel toponyma. Reflexe prostoru vztahujícího se $k$ toponymu se přirozeně může mezi jednotlivými uživateli lišit. $\mathrm{Z}$ toho důvodu rozlišujeme individuální objektovou fixaci a jádro objektové fixace. Jádrem je myšlen průnik individuálních reflexí prostoru, který musí nastat, aby toponymum mohlo plnit své onymické funkce v širším komunikačním rámci. Jádro objektové fixace tedy představuje objektivizovanou interpersonální fixaci toponyma (LÁBUS - VRBík 2018, 122). Možnosti výzkumu takto reflektované prostorové reality v interpersonálním vnímání naznačuje část 4.

Jádro objektové fixace je podle našeho názoru nutnou součástí propriálního (toponymického) obsahu. Ten lze chápat jako asociace, které u uživatelů zeměpisné jméno vyvolává, přičemž důležitou součástí těchto asociací jsou právě sdílené prostorově referenční aspekty.

Při modelování reálného světa na mapách či v prostředí geografických informačních systémů (GIS) dochází k nutnému zjednodušení zákresu prostorových jevů. 
Toponymické objekty jsou tak reprezentovány třemi základními entitami: bod, linie a plocha. Tento způsob vychází jak z charakteru studovaného jevu, tak z podrobnosti (měřítka) výsledného modelu. Druh toponymického objektu pak zásadně ovlivňuje i vztah mezi objektovou fixací ve vnímání jednotlivých uživatelů a jádrem fixace. $V$ př́padě označení bodových objektů (např́ḱlad kř́ž, pramen, skála) a objektů liniových (např́ílad vodní tok, cesta) lze předpokládat v podstatě úplnou shodu $\mathrm{v}$ jejich prostorovém vnímání, nebot reálná situace $\mathrm{v}$ terénu jinou fixaci nepřipouští. $\mathrm{V}$ př́padě plošných objektů polygonální povahy je už situace složitější. Existují sice plošné objekty s jasnou fixací svého pojmenování, jako je např́klad vodní plocha nebo náměstí v urbánním prostoru, častěji se ale setkáme s objekty, jejichž lokalizace není přesná. Typickým zástupcem takových objektů jsou pozemkové tratě, jejichž hranice nemusí být (a nejčastěji nejsou) v terénu a v jeho mentální reflexi jednoznačně vymezitelné. Podobné obtíže s jasným určením prostorového rozsahu nemají jen pozemková jména, ale také oronyma. Toponymický obsah kartografických děl zpravidla fixuje oronymum k vrcholové kótě, zatímco pojmenovatelé a uživatelé vnímají orografický objekt nejčastěji jako celek v korelaci s okolním terénem. Jména oronymických objektů, jejichž vertikální prominence není nijak výrazná, pak z hlediska své objektové fixace představují podobný problém jako jména pozemková.

Ani označení bodových objektů nemusí být vždy vnímáno jednoznačně. Jejich pojmenování svou dominancí v sociokulturním a komunikačním prostoru (jako reflexe jejich dominance $\mathrm{v}$ prostoru reálném) rozšiřují svou fixaci na své bezprostřední okolí, popř. na sousední objekty. V lučanské toponymii to ilustruje např́klad označení Na krojčenku (Krojčenk): původně šlo o jméno hostince (Kreuzschenke), jehož

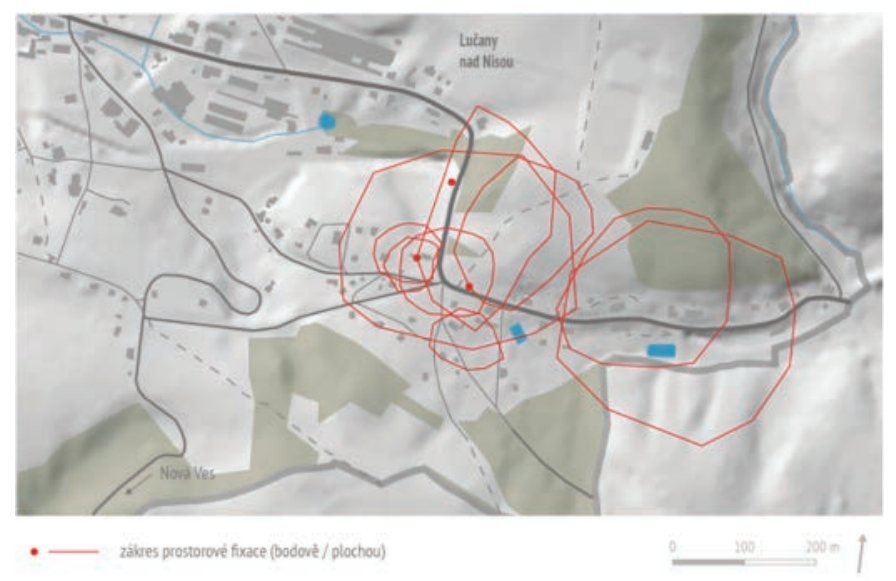

Obr. 1: Anoikonymum Na krojčenku (Krojčenk) a jeho objektová fixace. 
zchátralá budova byla odstraněna v roce 1974. Počeštěné jméno Krojčenk, konkurující si s předložkovou variantou Na krojčenku, označuje v Základní mapě ČR výrazné sedlo mezi Lučany nad Nisou a Smržovkou (630 m n. m.), jež překonává hlavní silnice č. 14, která se zde kříží s dalšími místními komunikacemi. Geonames eviduje předložkové pojmenování Na krojčenku jako název rozcestí. Jde o důležitý orientátor obyvatel Lučan nad Nisou a Smržovky, mezi nimiž leží. Jeho kartografická reprezentace, včetně databáze Geonames, naznačuje, že jde o bodový objekt. Z 12 respondentů, kteří objekt zakreslili (k výzkumu viz část 4), jej ale 9 vnímá jako objekt plošné povahy (viz obr. 1, dále $k$ tomu viz část 3).

Bodové objekty se navíc velmi často stávají objekty relačními (k pojmu relační objekt viz např́klad PlesKalová 2017a). Bod a jeho označení (např́íklad kř́žek) se může stát východiskem pro pojmenování objektu polygonální povahy (pozemek U kř́žku) a následně zde mohou vyvstat obdobné obtíže s postižením objektové fixace, jaké jsme naznačili výše.

\section{Změny objektové fixace a přenášení jmen}

Stabilita sdílené reflexe prostorové lokalizace je sice podstatou fungování toponymie, neznamená to ale, že by objektová fixace byla zcela neměnná. Z nejrůznějších příčin může $\mathrm{v}$ momentu užívání toponyma docházet $\mathrm{k}$ jejím změnám. Tyto změny mohou být rázu kvalitativního (změna povahy toponymického objektu) nebo kvantitativního (rozšíření či zúžení fixace). Změny fixace jsou podmíněny nejen proměnlivým vnímáním prostoru a jeho fyzickými proměnami, ale i vnímáním jeho kartografického ztvárnění. Způsob umístění toponymického obsahu v běžné topografické mapě může mít vliv na to, jak uživatel lokalizaci toponyma chápe. Především u plošných objektů pak lze ve vztahu mapa (tvůrce mapy) - uživatel hovořit o zužování objektové fixace.

Kvantitativní změny ve smyslu rozšíření fixace vyplývají ze způsobu zapojení toponyma do komunikace, resp. do sdíleného orientačního systému. Typicky sem patří rozšíření fixace jména bodových objektů nebo v urbanizovaném prostředí staveb (významné/veřejné budovy), které svou dominancí v mimojazykovém i jazykovém prostředí tvoří výrazný orientační bod, a jejich pojmenování se tak fixuje i na jejich bezprostřední, byt' ne zcela jednoznačně vymezitelné okolí. V lučanské toponymii to ukazuje např́klad lidové toponymum Blaník / U Blaníku, původně označující hotel (dnes uzavřený), který slouží jako relační objekt pro pojmenování středu města.

Jiným projevem kvantitativní změny fixace jsou úřední zásahy do názvů tekoucích vod. V lokálním názvosloví často nastává situace, že tentýž vodní tok má na různých katastrech různá jména (srov. KRŠKo 2002, 144-145). Je to způsobeno tím, že v lokálním prostoru jsou na identifikační a diferenciační funkce toponym 


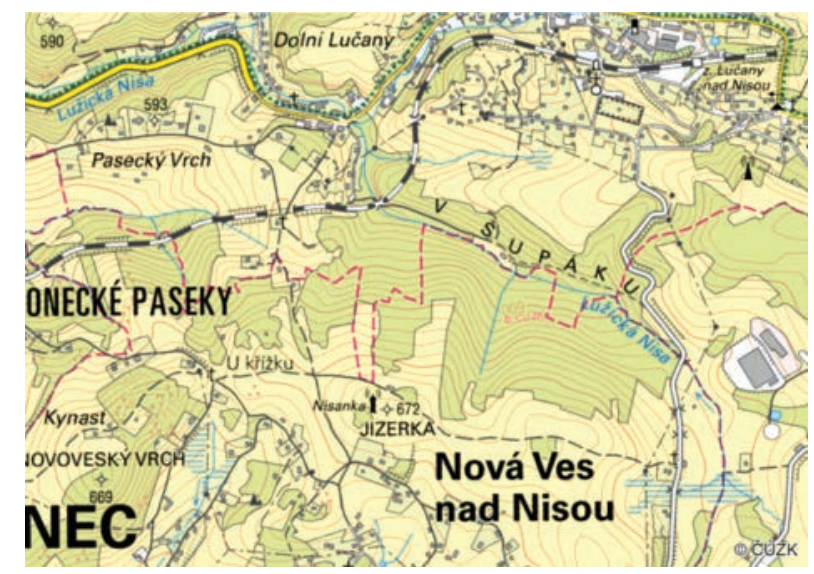

Obr. 2: Nejhořejší tok Lužické Nisy na Základní mapě ČR.

kladeny jiné požadavky než v makroprostoru (v celospolečenské komunikaci). Na katastru Lučan nad Nisou se to týká Lužické Nisy, vodního toku nadregionálního významu. Kartografické ztvárnění objektové fixace dvoučlenné formy Lužická Nisa se v průběhu času několikrát změnilo (odlišně vnímané pramenné toky). Současné vymezení toku Lužické Nisy v Základní mapě ČR se datuje do 9o. let 20. století (srov. LÁBus 2009, viz obr. 2). Výzkumy objektové fixace ale naznačují, že v lidové komunikaci běžní uživatelé ztotožňují uvedené toponymum až s úsekem toku v Dolních Lučanech od soutoku s Lučanskou Nisou (LÁBUS - VRBík 2018, 147).

$\mathrm{V}$ souvislosti se změnami fixace je ale třeba postihnout i její vztah $\mathrm{k}$ tzv. transonymizaci (tedy přenesení jména). Transonymizace se „zakládá na vztahu fundující proprium > proprium jiné tř́ídy či druhu“ "(PLESKALOVÁ 2017b, srov. též ŠRÁMEK $1999,56)$. R. Šrámek $(2016,207)$ nadto rozlišuje transonymizaci čistou (bez formální obměny) a transonymizaci rozšířenou (s formální obměnou). $V$ tomto textu ale pro zjednodušení užíváme termín transonymizace pouze ve smyslu přenášení jména bez dalších formálních změn, např́klad Slovanka [chata] - Slovanka [vrch]. Různým morfémovým obměnám (jak rozšířenou transonymizaci chápe ŠRÁMEK 2016, 205), ale i rozličným lexikálním rozšířením, at už předložkovým (vrch Slovanka rozcestí Pod Slovankou) či s využitím autosémantik (Wiesenthal - Ober Wiesenthal, Unter Wiesenthal), zde pozornost nevěnujeme.

Aplikace termínu transonymizace na nejrůznější změny, které probíhají v lokálních toponymických systémech, je ale značně komplikovaná. Názvy objektů, které uživatel vnímá jako dominantní, se běžně stávají východiskem pojmenování jiných objektů v jejich blízkém okolí (srov. Pleskalová 1992, 16, 66). Vznikne-li stejné pojmenování pro jasně vymezitelný objekt, obvykle jiného druhu, je účelné hovořit o transonymizaci, tedy přenesení jména na základě metonymické (prostorové) 
souvislosti. ${ }^{1}$ Výsledkem jsou dvě formálně shodná toponyma pro dva prostorově blízké objekty, tzn., že jde o „...[výsledek] dvou různých propriálně pojmenovacích aktů, které dokonce představují i dvě různé chronologické vrstvy“ (ŠRÁMEK 2016, 204). Př́́kladem je novodobé označení přírodní rezervace Malá strana na katastrálním území Horní Maxov, která bezprostředně sousedí s místní částí se shodným názvem (pravopisně ovšem Malá Strana, německy Kleinseite). Totéž se týká častého případu pojmenování zastávek hromadné dopravy, srov. hostinec Fatra v Lučanech nad Nisou a protější stejnojmenná zastávka příměstské autobusové dopravy. Důležité je, že v první řadě uživatelé, př́ípadně ve druhé řadě kartografická reprezentace v daném prostoru vnímají dva toponymické objekty s odlišnou referencí.

Naproti tomu v mnoha př́padech nelze jednoznačně identifikovat sekundární objekt jakožto př́jemce pojmenování. Označení dominantního objektu slouží jako prostředek $\mathrm{k}$ pojmenování jeho okolí - to je ale $\mathrm{z}$ hlediska přesného prostorového vymezení poněkud amorfní. Takové př́pady je podle našeho názoru vhodné považovat za kvantitativní rozšíření objektové fixace. Př́kladem z lučanské toponymie je lidové označení Modrá hvězda (též Avicenum) původně hotel Blauer Stern (krátce po roce 1945 fungoval s př̀ekladovým označením, po roce 1948 vystřídal celou řadu jmen, v současnosti je objekt mimo provoz). Toponymum Modrá hvězda / Avicenum je součástí lidového orientačního systému a označuje nejen objekt samotný, ale i bezprostřední okolí, přičemž jeho prostorové vymezení (rozsah) je značně vágní.

Jméno dominantního objektu může generovat obě linie: transonymizaci i rozšíření fixace. Takovým př́íkladem je zmíněné lidové toponymum Blaník, jež kromě rozšíření fixace z budovy bývalého hotelu (1) inspirovalo i pojmenování přilehlé autobusové zastávky (2). V př́padě (1) jde o označení nejbližšího, byt ne zcela jasně vyhraněného okolí budovy a podle našeho názoru jde o rozšířenou fixaci. Př́pad (2) pojmenovává autobusovou zastávku jako odlišný, jednoznačně vymezitelný objekt a jde o transonymizaci. Zasahuje-li tedy šířji vnímaný okolní prostor i nějaký orientačně a komunikačně výrazný objekt, dochází $\mathrm{k}$ transonymizaci, a tím $\mathrm{k}$ paralelní existenci dvou formálně shodných toponym.

Hranice mezi rozšířením fixace a transonymizací je však velmi neostrá. Při posuzování je třeba brát v potaz nejrůznější mimojazykové i vnitrojazykové faktory, které ovlivňují percepci a pojmenování konkrétního objektu. Jako podstatné se pro stanovení rozdílu mezi rozšířenou fixací a transonymizací ukazuje především ta skutečnost, zda v daném prostoru uživatelé (a pojmenovatelé) vnímají jeden onymický objekt nebo více onymických objektů.

Kvalitativní změnou objektové fixace je myšlena změna povahy objektu, která je obvykle důsledkem zániku původního objektu. Objekt 1 označený jménem A zaniká

1 Srov. heslo „Vlastní jméno metonymické“ v Novém encyklopedickém slovníku češtiny: „Vlastní jméno vzniklé na základě věcné, zvláště vnitřní (časové, prostorové [zvýraznili autoři], kauzální) souvislosti pojmenovávaného objektu s jiným." (Pleskalová 2017c) 
a na jeho místě vzniká objekt 2, pro jehož identifikaci se nadále používá pojmenování $\mathrm{A}$. Ze synchronního hlediska jde tedy o jeden toponymický objekt. Z hlediska diachronního jde ale o dva objekty různého druhu. L. Olivová-Nezbedová proto tuto změnu řadí k transonymizaci (1996, 133, viz též ŠRÁMEK 1999, 69), přičemž i tyto případy lze hodnotit jako přenos metonymické povahy (viz ŠTĚPÁN 2007, 68). V lučanské toponymii je takovým př́kladem zaniklá sídelní enkláva Pohlberg (česky před rokem 1945 ojediněle U Pohlů, po odsunu Němců již trvale neosídlená a v 60. letech fakticky zaniklá), na jehož místě uvádí databáze Geonames anoikonymum Pohlův vrch (evidované jako lesní pozemek). L. Olivová-Nezbedová dále v této souvislosti doplňuje, že nový „prostor může být a) totožný, b) větší, c) menši“ (1996, 133). Přesné prostorové vymezení zaniklého, ale i současného objektu je však v reálné situaci nemožné.

Právě radikální zásahy do přirozeného vývoje toponymie, jako byl např́íklad odsun německého obyvatelstva z Československa, výrazně ovlivňují i obraz objektové fixace. Jak jsme ukázali v předchozí studii (LÁBus 2018), hlavní osu německé toponymie v Lučanech nad Nisou tvořila pojmenování relativně samostatných sídelních lokalit roztroušených ve značně členitém katastru. Jejich typickou strukturu tvořilo antroponymum + oronymické apelativum (např́klad zmíněné Pohlberg, dále Weisskoppe, Jakobsberg, Ferdinandsberg aj.). Většina jejich českých ekvivalentů, pokud existují, byla do oficiální toponymie reintrodukována až po roce 2000 a databáze Geonames je neeviduje jako místní jména (jména místních částí), ale jako oronyma. Hypoteticky mohou v současnosti takové formy označovat jak orografický objekt, tak místní část, jak ukazuje L. Olivová-Nezbedová (1996, 133): „Objekt je pojmenován jménem sousedního (= iradiace); jméno se po přenesení vztahuje jak na původní prostor, tak na přilehlý." Prověření jejich skutečné fixace v lidovém orientačním systému by však spolehlivé výsledky nepřineslo, protože podle šetření mají zpravidla o-1 aktivního uživatele (podrobněji viz LÁBus 2018, 133-134).

Je však třeba zdůraznit, že za hlavní příčinu změn objektové fixace nepovažujeme reálné proměny objektu, ale proměny orientačních, identifikačních a diferenciačních potřeb pojmenovatelů a uživatelů. Počet pojmenovaných objektů odpovídá aktuálním potřebám obyvatel př́slušné lokality ${ }^{2}$ a totéž platí i pro jejich objektovou fixaci. Typickým př́kladem je tedy stav, že označení významného objektu pojmenovává širší lokalitu z důvodu nově vyvstanuvší orientační potřeby, a to pro jeho dominanci v reálném, mentálním i komunikačně sdíleném prostoru. Otázku, kdy jde o přenesení jména na odlišný onymický objekt a kdy jde o rozšíření fixace, jsme diskutovali výše. V obou př́padech je však příčina totožná.

$2 \quad \mathrm{~V}$ této souvislosti připomeňme slova prof. Jany Pleskalové, která zazněla v diskusi po jejím vystoupení na konferenci Variantnost $v$ onymii a $v$ dialektech v Brně 17. ledna 2019: „Pomístních jmen není nikdy ani málo, ani moc. Vždy je jich tolik, kolik jich je potřeba.“ 


\section{Možnosti výzkumu objektové fixace}

Jak jsme naznačili v části 2, běžná topografická mapa, jako zjednodušený obraz reality, není s to poskytnout přesnou informaci o objektové fixaci toponym. Týká se to především toponym vázaných $\mathrm{k}$ plošným jevům, které však v krajině nemají jednoznačně definovatelnou a viditelnou hranici. Nedostatky v zachycení a ztvárnění objektové fixace lze však překlenout metodami a nástroji GIS. Ty je možné použít jak pro výzkum, tak prezentaci objektové fixace toponym z pohledu uživatelů.

Pro základní sběr dat se mohou využít dvě metody: (1) specializovaný software, který umožňuje respondentům zakreslit do slepé digitální mapy prostorový vjem konkrétního toponyma, (2) tištěnou slepou mapu se stejným účelem. Obě tyto metody byly testovány v rámci projektu Studentské grantové soutěže s názvem Toponyma $v$ krajině: jejich struktura a proměny, který realizovali pracovníci a studenti Fakulty př́rodovědně-humanitní a pedagogické Technické univerzity v Liberci v letech 2016-2018 (o projektu viz LÁBUS - VRBík 2018, 13-14).

Pro sběr dat o vnímání objektové fixace byl nejprve využit tablet se softwarem Collector for ArcGIS. Jeho prostřednictvím probíhal výzkum v roce 2017 ve městě Vysoké nad Jizerou (okres Semily) a zúčastnilo se jej 13 respondentů. Práce s tabletem a interaktivní mapou ale může být pro některé, především starší respondenty, kteř́ nejsou zcela zvyklí pracovat s moderní technikou, problematická. Z toho důvodu je vhodné metodu sběru pomocí tabletu kombinovat se zákresem do analogových map velkých měřítek nebo ji analogovým sběrem dat zcela nahradit. Nevýhodou analogového sběru je větší objem práce při zpracování dat a možné neúmyslné zanášení chyb při jejich zpracování. Předlohy je totiž nutné nejprve převést do digitální podoby skenováním, následně je v prostředí GIS georeferencovat, tzn. umístit do zeměpisných souřadnic, vektorizovat a doplnit jim př́slušné atributy. V každém kroku však dochází k určitým zkreslením.

Tištěné slepé mapy byly využity pro sběr dat o objektové fixaci na území města Lučany nad Nisou. Průzkum probíhal v průběhu roku 2018 a účastnilo se jej 14 respondentů. Pro každého respondenta byla připravena topografická mapa se stínovaným reliéfem bez toponymického obsahu, vytištěná na dvou listech velikosti A3. Úkolem každého respondenta bylo zakreslit, jak vnímá prostorové ukotvení 20 předem vybraných toponym (samozřejmě za předpokladu, že je zná).

Další fází výzkumu bylo zpracování a analýza získaných dat prostřednictvím metod GIS. Analýza dat měla poskytnout odpověd' na otázku, v jakém prostoru jsou vybraná toponyma lokalizována a zda dochází mezi respondenty ke shodě, tj. zda je možné vymezit jádro objektové fixace. Na obě otázky je možné nalézt odpověd' prostým přeložením zákresů jednotlivých respondentů přes sebe, jak ukazuje obr. 3 na př́kladu vnímání fixace toponyma Pasecký Vrch (lidově Pasečák). Podle Základní mapy ČR a databáze Geonames jde o místní část, což reflektuje i pravopisné ztvárnění. České jméno vzniklo překladem německého pojmenování Schlager Berg, mo- 
tivovaného blízkostí obce Schlag, česky Jablonecké Paseky (dnes součást města Jablonec nad Nisou). Většina individuálních zákresů směřuje do prostoru, do něhož se jméno fixuje i v oficiálních kartografických dílech, tzn. $\mathrm{k}$ liniové zástavbě podél místní komunikace vedoucí po táhlém hřbetu jižně od údolí s hlavní silnicí č. 14 a tokem Lužické Nisy (srov. obr. 4). Jednotlivé zákresy však vykazují překvapivě velký rozptyl. Ten může být způsoben třemi faktory: (1) absence jasných geomorfologických i sídelních hranic a dominant (s výjimkou severní části), (2) nejasná povaha objektu oscilující mezi sídelním a nesídelním prostorem a s tím související

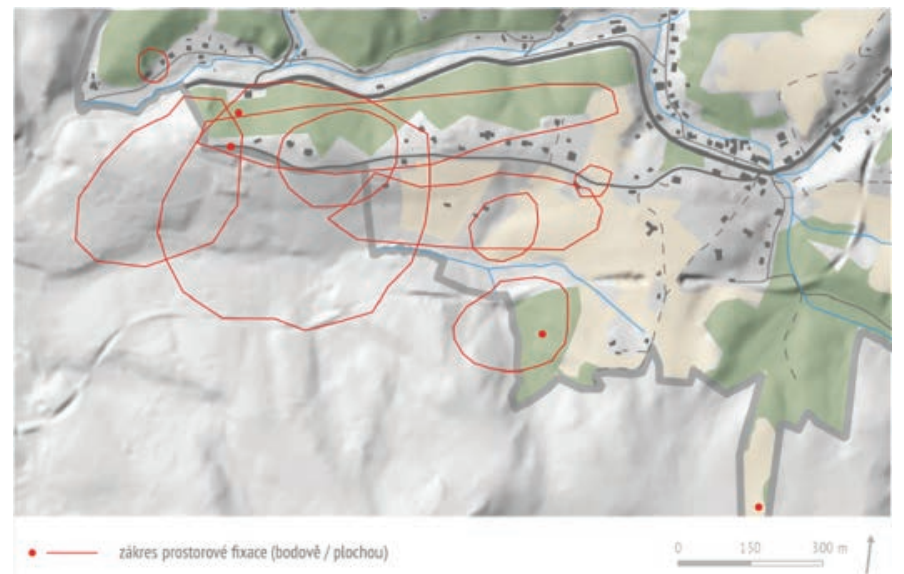

Obr. 3: Vnímání fixace toponyma Pasecký Vrch (lidově Pasečák).

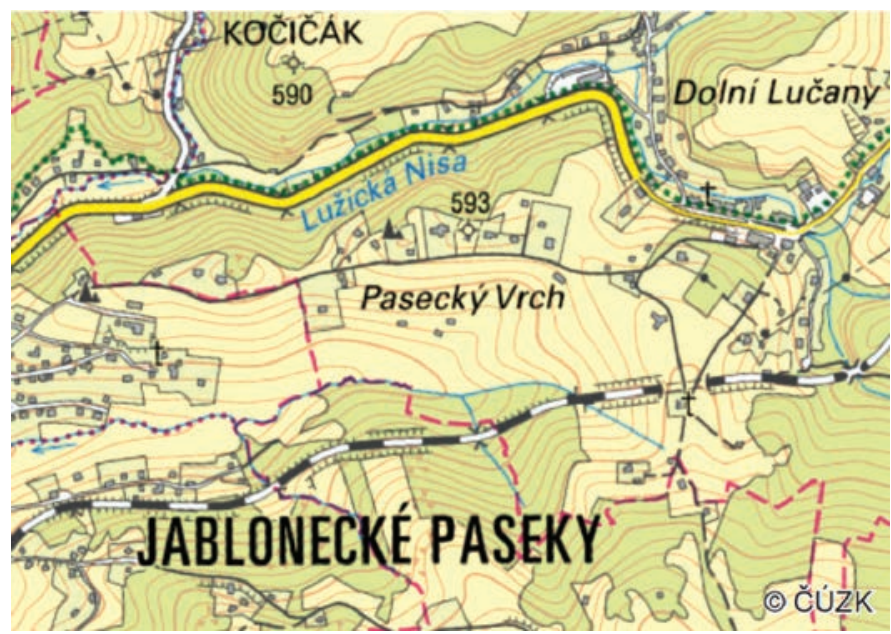

Obr. 4: Umístění toponyma Pasecký Vrch v Základní mapě ČR. 
rozpor mezi formou pojmenování (obsahující oronymické apelativum vrch) a v databázích deklarovaným sídelním charakterem objektu, (3) horší orientace respondentů v mapovém podkladě, resp. neschopnost projektovat vnímání reálného prostoru do jeho kartografické reprezentace (k tomu viz dále).

Jednoduché zachycení jednotlivých zákresů (obr. 3) však neumožňuje výsledek kvantifikovat, tzn. určit, kolik respondentů se v jakém místě na fixaci shoduje. Proto byla vektorová data pro potřeby analýzy převedena do rastrové podoby (čtvercová sít') o velikosti buňky 10 × 10 metrů. Takto připravené rastry bylo možné následně mezi sebou sčítat a kvantitativně tak vyhodnotit průniky zákresů objektové fixace toponym např́č respondenty, tedy jádro fixace, jak dokládá obr. 5 (také na př́ikladu toponyma Pasecký Vrch). Značný rozptyl zákresů (viz obr. 3) ovlivnil i jasné vymezení jádra objektové fixace. Největší překryv posouvá jádro objektové fixace o něco západněji, než je pozice toponyma v základní mapě (srov. obr. 4), dokonce až na hranice katastrálních území Lučany nad Nisou a Jablonecké Paseky - v této souvislosti se tak nabízí otázka, zda více než terénní situace neovlivnilo úsudek respondentů samotné toponymum s určující částí deoikonymického původu (Pasecký). Osou takto vymezeného jádra fixace je ale stále místní komunikace podél občanské zástavby.

Vyhodnocování získaných dat poukázalo na některé problémy, které takto pojatý výzkum objektové fixace přináší. Prvním problémem je otázka, jaká toponyma zkoumat. Každý areál (katastr obce) je zaplněn řádově desítkami až stovkami toponym. V rámci zmíněného projektu Toponyma $v$ krajině: jejich struktura a proměny bylo na území katastru Lučany nad Nisou zachyceno 298 variant pro 127 toponymických objektů. Pro zajištění co nejvyšší objektivity výzkumu je však třeba zaměřit se na taková toponyma, u nichž se předpokládá vysoká míra interpersonální zna-

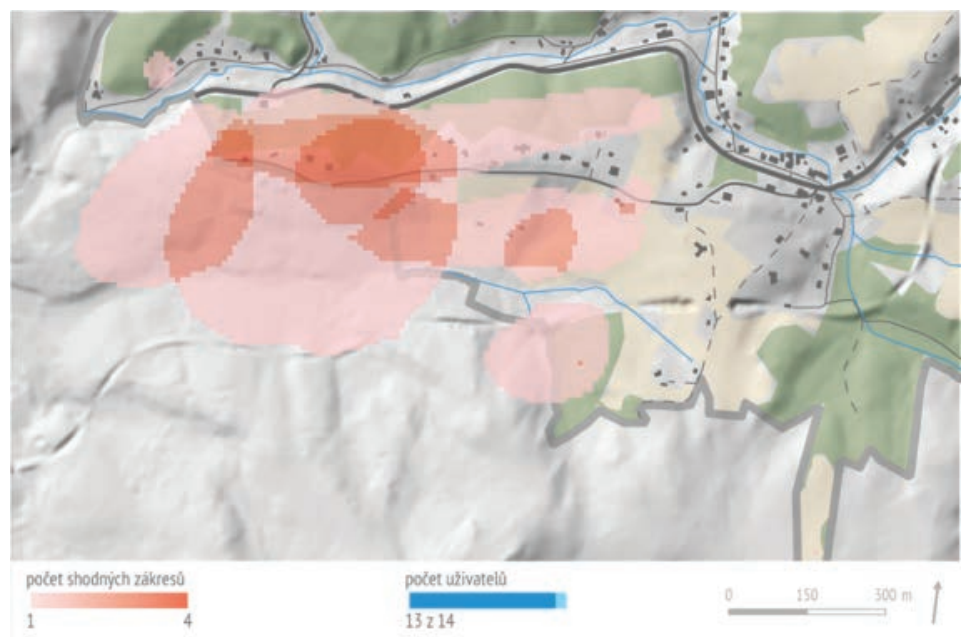

Obr. 5: Jádro objektové fixace toponyma Pasecký Vrch. 
losti. Zkoumaná toponyma tedy musí být respondentům dostatečně známá, měla by být součástí aktivního užívání. Výzkumu objektové fixace tak musí předcházet výzkum tzv. toponymického centra, jehož cílem je zjistit, která toponyma (varianty) vykazují nejvyšší znalost mezi uživateli (resp. respondenty) a tvoří tak páteř orientačního systému př́slušné lokality (k výzkumu a interpretaci toponymického centra viz LÁBUS - VRBíK 2018, 51-74). Z toho důvodu bylo do výzkumu objektové fixace $v$ Lučanech nad Nisou zařazeno pouze 20 toponym, u nichž byla předchozím dotazníkovým šetřením zjištěna alespoň 5oprocentní aktivní znalost.

Druhý problém představuje výběr respondentů. Z hlediska kvantitativních požadavků je komplikované stanovit, kolik respondentů tvoří statisticky reprezentativní vzorek, jenž zajistí dostatečnou objektivitu dat. Výzkumu objektové fixace se v Lučanech nad Nisou zúčastnilo 14 respondentů, což nepředstavuje př́liš početný vzorek, a proto i malá odchylka může způsobit výraznou chybu v interpretaci. Vypovídací hodnotu má tedy především samotné jádro objektové fixace. I tak je ale nutné $\mathrm{k}$ výsledkům takové analýzy přistupovat obezřetně a brát $\mathrm{v}$ potaz míru nejistoty, která s daty přichází. Jako nejvíce limitující faktor, který ovlivnil spolehlivost získaných dat, se ale $\mathrm{v}$ průběhu výzkumu ukázala schopnost respondentů pracovat $s$ mapou. Respondenti obecně měli problém orientovat se ve slepém mapovém podkladu a vnímat kartografickou reprezentaci krajiny v korelaci se svou mentální představou reálné terénní situace. Značný rozptyl jednotlivých zákresů (srov. obr. 1 a obr. 3) tak může být v mnoha prípadech zapříčiněn nikoli nevyhraněnou fixací toponyma, ale spíše chybným čtením mapy (resp. zakreslením do ní).

\section{Závěr}

Objektová fixace toponym představuje reflexi toho, jak uživatelé vnímají toponyma ve vazbě na skutečnou terénní situaci. Výzkum interpersonálně sdílené reflexe, již nazýváme jádrem objektové fixace, naznačuje, jaké prostorové informace jsou v jednotlivých toponymech zakódovány jako nutná součást jejich propriálního obsahu. Výzkum objektové fixace umožňují nástroje a metody geografických informačních systémů. Tyto prostředky tak toponomastický výzkum obohacují o zcela novou prostorovou dimenzi.

Výzkum objektové fixace $v$ Lučanech nad Nisou přinesl několik otázek vhodných $\mathrm{k}$ dalšímu studiu. Kromě zmíněného stanovení reprezentativního vzorku jde naprŕklad o to, jak by měla vypadat mapa pro výzkum fixace toponym, aby nebyla návodná $\mathrm{z}$ hlediska zákresu a zároveň se v ní většina respondentů dokázala zorientovat. Další otázkou je, jakou roli hraje vzájemná blízkost objektů toponymického jádra na vjem prostorové fixace, tedy zda dochází k překrytí prostorových fixací několika blízkých objektů. Na tyto a další otázky se autoři zaměřují v navazujících výzkumech. 


\section{LITERATURA}

KRŠKo, Jaroslav. 2002. Mikroštruktúrne vztahy v onymii. Slovenská reč 67(3), 142-153.

LÁBus, Václav - VRBík, Daniel. 2018. Toponyma v krajině a možnosti jejich výzkumu. Liberec: Technická univerzita v Liberci.

LÁBus, Václav. 2009. Pojmenování Lužické Nisy a jejích zdrojnic v proměnách času. Acta onomastica 50, 143-151.

LÁBus, Václav. 2014. Poznámky k tzv. mikrostrukturním vztahům v onymii. In: MinÁŘová, Eva - Sochorová, Dagmar - Zítková, Jitka, eds. Vlastní jména v textech a kontextech. Brno: Masarykova univerzita, 47-52.

LÁBus, Václav. 2018. Klingerova díra, nebo Zvonkové údolí? Poznámky k vývoji toponymie v bývalých Sudetech. Acta onomastica 59, 123-141.

OlivovÁ-NezBedová, Libuše. 1996. Poznámky k přenášení jmen v toponymii. Acta onomastica 37, 133-135.

Pleskalová, Jana. 1992. Tvoření pomístních jmen na Moravě a ve Slezsku. Jinočany: $\mathrm{H} \& \mathrm{H}$.

Pleskalová, Jana. 2017a. Relační objekt. In: CzechEncy - Nový encyklopedický slovník češtiny [online]. [7. 3. 2018]. Dostupné z: https://www.czechency.org/slovnik/RELAČNí OBJEKT

Pleskalová, Jana. 2017b. Transonymizace. In: CzechEncy - Nový encyklopedický slovník češtiny [online]. [7. 3. 2018]. Dostupné z: https://www.czechency.org/slovnik/TRANSONYMIZACE

Pleskalová, Jana. 2017c. Vlastní jméno metonymické. In: CzechEncy - Nový encyklopedický slovník češtiny [online]. [7. 3. 2018]. Dostupné z: https://www.czechency.org/slovnik/ VLASTNÍ JMÉNO METONYMICKÉ

ŠRÁMEK, Rudolf. 1999. Úvod do obecné onomastiky. Brno: Masarykova univerzita.

ŠRÁMEK, Rudolf. 2016. Transonymizace v propriální nominaci. In: ŠRÁMEK, Rudolf. Labyrintem vlastních jmen a nářečí. Brno: Host, 201-209.

ŠTĚPÁN, Pavel. 2007. K prostorovým vztahům v toponymii (problematika metonymie v zeměpisných jménech). In: Koten, Jiří, ed. Prostor v jazyce a literatuře. Ústí nad Labem: Univerzita Jana Evangelisty Purkyně, 65-68.

\section{Václav Lábus}

Faculty of Science, Humanities and Education

Technical University of Liberec

Studentská 2, 46117 Liberec

Czech Republic

vaclav.labus@tul.cz

\section{Daniel Vrbík}

Faculty of Science, Humanities and Education

Technical University of Liberec

Studentská 2, 46117 Liberec

Czech Republic

daniel.vrbik@tul.cz 